Katarzyna Arciszewska*

AgnieszKa WojcieszaK ${ }^{* *}$

\title{
DROIT MORAL, KTÓRE NIE MA NIC WSPÓLNEGO Z MORALNOŚCIĄ, CZYLI O AUTORSKICH PRAWACH OSOBISTYCH W SYSTEMIE PRAWA FRANCUSKIEGO
}

La parole n'est qu'un bruit et les livres ne sont que du papier'.

(Paul Claudel)

\section{Wstęp}

Celem niniejszego artykułu jest przybliżenie konstrukcji autorskich praw osobistych w kształcie przyjętym przez francuskiego ustawodawcę, ze szczególnym uwzględnieniem prawa do ujawnienia dzieła oraz prawa do integralności dzieła, co autorki postarają się przedstawić poddając analizie zarówno istniejące $\mathrm{w}$ tym zakresie ustawodawstwo, jak i bogate orzecznictwo francuskich sądów cywilnych.

Omawiając kwestię ochrony autorskich praw osobistych poczynić należy uwagę natury ogólnej, że domeną kontynentalnego systemu prawa jest istnienie dwóch modeli konstrukcji treści prawa autorskiego. Pierwszym z nich jest model określany jako „dualistyczny" (występujący oprócz systemu francuskiego także we Włoszech, Hiszpanii czy Polsce), charakteryzujący się wyodrębnieniem dwóch samodzielnych praw autorskich: praw majątkowych i praw osobistych ${ }^{2}$. Różnice istniejące pomiędzy rodzajami tych praw dotyczą w szczególności czasu trwania praw, zasad określenia uprawnionego podmiotu czy też środków służących ochronie

* Mgr, Uniwersytet im. Adama Mickiewicza w Poznaniu; e-mail: k.arciszewska@op.pl

** Mgr, Uniwersytet im. Adama Mickiewicza w Poznaniu; e-mail: wojcieszak-agnieszka@wp.pl

1 "Słowo nie jest tylko hałasem a książka nie jest tylko papierem”.

${ }^{2}$ L. Górnicki, Rozwój idei praw autorskich od starożytności do II wojny światowej, Wrocław 2013, s. 34. 
tych praw. W koncepcji „dualistycznej” zakłada się zatem istnienie wielu dóbr i skorelowanych z nimi odrębnych praw podmiotowych ${ }^{3}$. Z kolei drugim z występujących modeli jest tzw. „,monistyczny" model konstrukcji praw autorskich, szczególnie eksponowany w ustawodawstwie Niemiec i traktujący uprawnienia osobiste i majątkowe jako składniki jednolitego, niezbywalnego prawa przysługującego twórcy ${ }^{4}$. Przedmiotem obrotu w modelu „monistycznym” mogą być poszczególne uprawnienia, z tym jednak zastrzeżeniem, że podstawą takiego obrotu nie jest przeniesienie praw (cesja), lecz ustanowienie ich na rzecz innej osoby. Jedynie na marginesie wskazać należy, iż anglosaski system prawny traktuje prawo autorskie jako zespół uprawnień majątkowych (copyright) służących ochronie interesów twórcy i zapewnieniu rozwoju nauki oraz sztuki ${ }^{5}$.

Niekwestionowanym prekursorem dla powstania praw autorskich w kontynentalnym systemie prawnym jest Francja. Już bowiem w czasach rewolucji francuskiej należy doszukiwać się koncepcji ideologicznych mających za przedmiot ochronę interesów niemajątkowych twórcy ${ }^{6}$. Swoisty fenomen Francji w tej sferze tkwi w fakcie, iż podstawą systemu ochrony praw autorskich stała się praktyka sądownicza. Niezaprzeczalne oddziaływanie judykatury w dziedzinie poszukiwania podstaw konstrukcji normatywnych oraz treści autorskich praw osobistych jest jedną z charakterystycznych cech systemu droit moral (autorskie prawo niemajątkowe) i nie traci na aktualności od czasów rewolucji francuskiej

Od połowy XIX w. sądy francuskie wydawały orzeczenia, w których odwoływały się do osobistych interesów autora, przyjmując za podstawę rozstrzygnięć treść art. 1382 francuskiego kodeksu cywilnego, który stanowi klauzulę generalną odpowiedzialności deliktowej ${ }^{8}$. Pierwszym przypadkiem orzeczenia, w którym sąd odwołał się do osobistego aspektu prawa autorskiego był wyrok wydany w sprawie Billecocq v. Glendaz, w 1814 r. ${ }^{9}$, w którym sąd orzekł, że praca, która została sprzedana przez

${ }^{3}$ T. Konach, Autorskie prawa osobiste w ustawodawstwach Francji i Republiki Federalnej Niemiec - analiza prawnoporównawcza, "Ruch Prawniczy, Ekonomiczny i Socjologiczny” 2014, z. 3, s. 2.

4 Tamże, s. 3.

${ }^{5}$ L. Górnicki, Rozwój idei, s. 40.

${ }^{6}$ A. Niżankowska, Prawo do integralności utworu, Warszawa 2007, s. 42.

${ }^{7}$ K. Czub, Konstrukcja i treść podstawowych autorskich praw osobistych w systemie prawa francuskiego, "Studia Iuridica Toruniensia” 2009, t. 5, s. 92.

8 "Tout fait quelconque de l'homme, qui cause à autrui un dommage, oblige celui par la faute duquel il est arrivé à le réparer” („Każdy kto wyrządził szkodę obowiązany jest do jej naprawienia").

${ }_{9}$ Tribunal civil de la Seine, 17 août 1814. 
autora sprzedawcy książek lub drukarzowi i która miała zostać opatrzona nazwiskiem autora, musi zostać wydrukowana w postaci, w jakiej została sprzedana i dostarczona ${ }^{10}$. W $1848 \mathrm{r}$. w sprawie Clésinger $i$ Laneuville v. Gauvain artysta rzeźbiarz domagał się wszczęcia procedury karnej przeciwko nabywcy stworzonej przez niego rzeźby, twierdząc, że ten ostatni dopuścił się jej okaleczenia ${ }^{11}$. W uzasadnieniu orzeczenia sąd wskazał, iż niezależnie od interesu pieniężnego, artysta ma także interes o wiele cenniejszy, ten, który odnosi się do jego reputacji. Na skutek apelacji pozwanego, sąd wyższej instancji powództwo oddalił, przyjmując, że procedura karna była w tej sprawie niewłaściwa, niemniej jednak wskazał, iż powództwo cywilne byłoby uzasadnione.

\section{Pojęcie droit moral i normatywne źródła autorskich praw osobistych}

Po raz pierwszy termin określający autorskie prawa niemajątkowe (droit moral) pojawił się w artykule francuskiego teoretyka André Morillota opublikowanym w $1872 \mathrm{r}^{12} \mathrm{~W}$ publikacji autor określił prawa niemajątkowe jako nierozłącznie związane ze osobą („,exclusivement attachés à la personne") i choć sformułowanie to użyte zostało wówczas w kontekście odpowiedzialności kontraktowej i korespondowało z regulacją zawartą w kodeksie Napoleona ${ }^{13}$, stało się jednak przyczyną bardziej szczegółowych rozważań w tym temacie. W przywoływanym artykule A. Morillot wskazał na istnienie praw należących co prawda do systemu prawa własności lecz nie dających się wyrazić w pieniądzu, które to prawa określił terminem droit moral ${ }^{14}$. Termin droit moral w znaczeniu, jakim posłużył się nim A. Morillot, w orzecznictwie sądów francuskich użyty został w wyroku sądu kasacyjnego wydanym w sprawie Cinquin v. Lecocq ${ }^{15}$, gdy sąd

${ }^{10} \mathrm{~K}$. Czub, Konstrukcja i treść podstawowych autorskich praw osobistych w systemie, s. 97.

11 Tribunal correctionnel de Lyon, 5 janvier 1850.

12 A. Morillot, De la personnalité du droit de copie qui appartient à un auteur vivant, Paris 1872, s. 78.

${ }^{13}$ Obecnie art. 1166 Code civil: „néanmoins, les créanciers peuvent exercer tous les droits et actions de leur débiteur, à l'exception de ceux qui sont exclusivement attachés à la personne” („Wierzyciel uprawniony jest do egzekwowania praw i czynności od swojego dłużnika, z wyjątkiem tych bezpośrednio związanych z osobą dłużnika").

${ }^{14}$ Językowo przymiotnik moral można uznać za synonim przymiotnika "duchowy", „umysłowy".

${ }^{15}$ Cour de Cassation, 25 juin 1902. 
pierwszej instancji potraktował utwory rozwodzącego się kompozytora, jako współwłasność małżonków i podzielił je pomiędzy nich. Zarówno na podstawie treści przekazanych przez A. Morillota, jak i ówcześnie wydawanych orzeczeń sądowych, prawa osobiste autora obejmowały zasadniczo prawo do decydowania o rozpowszechnianiu, atrybucji dzieła oraz do ochrony przed nieautoryzowaną publikacją ${ }^{16}$.

Normatywnym źródłem osobistych praw autorskich we francuskim systemie prawnym była ustawa z dnia 11 marca 1957 r. o własności literackiej i artystycznej ${ }^{17}$, która uchyliła uchwalone $\mathrm{w}$ czasach rewolucji francuskiej ustawy z 13-19 stycznia 1791 r. i 19-24 lipca 1793 r. Ustawa z dnia 11 marca 1957 r. po raz pierwszy zawierała regulację normatywną dotyczącą autorskich praw osobistych, wypracowaną przez dotychczasowe orzecznictwo ${ }^{18}$. Przepisy zawarte $\mathrm{w}$ tej ustawie inkorporowano następnie do obecnie obowiązującej ustawy z dnia 1 lipca 1992 r. - kodeks własności intelektualnej ${ }^{19}$, która poświęca autorskim prawom osobistym rozdział I (w części I, księga I, tytuł II) - Droits moraux (Prawa osobiste niemajątkowe).

Mając na względzie spójność wyrażonych poniżej wywodów odnoszących się do regulacji normatywnych przyjętych przez francuskiego ustawodawcę, wskazać należy, że podstawę dla osobistych uprawnień autora stanowi w prawie francuskim uznanie niepodzielności osoby twórcy i jego dzieła. Powyższe znajduje odzwierciedlenie w koncepcji personalistycznej, zakładającej, iż pojęciem zasadniczym jest utwór powstały w wyniku działalności intelektualnej (kwalifikowanej jako akt twórczy), a będący emanacją osobowości twórcy ${ }^{20}$. Dlatego też art. L.111-1 Code de la propriété intelectuelle (Kodeks własności intelektualnej) stanowiący swego rodzaju definicje praw autorskich (a przynajmniej wyrażający ich naturę) wskazuje, iż są to atrybuty intelektualne i osobiste autora, albowiem utwór, jako uzewnętrznienie osobowości autora stanowi urzeczowione przymioty intelektualne i osobiste samego autora ${ }^{21}$.

${ }^{16}$ C. Colombet, Propriété littéraire et artistique et droit voisins, Paris 1994, s. 76.

${ }^{17}$ Loi N 57- 298 du 11 mars 1957 sur la propriété littéraire et artistique [dalej: ustawa z dnia 11 marca 1957 r.].

18 P-Y. Gautier, Propriété littéraire et artistique, Paris 1990, s. 110.

${ }^{19}$ Loi N 92-597 du 1er juillet 1992 relative au code de la propriété intelectuelle [dalej: Code de la propriété intelectuelle].

${ }^{20}$ H. Debois, Le droit d'auteur en France, Paris 1978, s. 45.

${ }^{21}$ „Ce droit comporte des attributs d'ordre intellectuel et moral ainsi que des attributs d'ordre patrimonial” („Na prawo to składają się przymioty osobiste i niemajątkowe autora, które wyrażone są w materialnej postaci"). 
Treść powyżej przytoczonego przepisu niejako wymusza pochylenie się nad kwestią reguł klasyfikujących poszczególne dobra niematerialne jako utwór. Wobec powyższego wskazać należy, iż przesłanka twórczości zrealizowana jest wówczas, gdy istnieje subiektywnie nowy wytwór intelektu ${ }^{22}$. Odpowiednie normy prawne przewidują uznanie indywidualności dzieła, poprzez przyjęcie wyróżnika oryginalności, który jednak odnosi się jedynie do powiązania dzieła z osobowością twórcy ${ }^{23}$. Code de la propriété intelectuelle nie wprowadza zatem żadnej dodatkowej przesłanki poddania utworu prawu autorskiemu (jak np. cel powstania dzieła, postać, jakość czy rozmiar) ${ }^{24}$. Istotne jest jedynie istnienie faktycznego indywidualnego wkładu. Na mocy analizowanego przepisu konstrukcja uprawnień osobistych twórców oparta jest na koncepcji praw podmiotowych o skuteczności erga omnes ${ }^{25}$. Warty nadmienienia zdaje się również być fakt, że w ustawodawstwie francuskim, pozycja autora została dodatkowo literalnie wzmocniona przez postanowienia przywoływanego przepisu art. L. 111-1 Code de la propriété intelectuelle, iż twórca nabywa wyłączne i absolutne prawo własności intelektualnej na podstawie samego aktu twórczego (, du seul fait de sa création” $)^{26}$. Z brzmienia ustalonego przez analizowany przepis wysnuć należy wniosek, że tylko osoba fizyczna może być autorem, gdyż Code de la propriété intelectuelle, jedynie na zasadzie fikcji prawnej traktuje osoby prawne jako autorów ${ }^{27}$. Jak wynika z analizy przepisów kodeksu, jedynym dopuszczalnym wyjątkiem (czyli uznaniem osoby prawnej za twórcę) są dzieła zbiorowe powstałe z inicjatywy osoby prawnej, co ma służyć określeniu sytuacji prawnej specyficznych wytworów literackich, jakimi są słowniki, encyklopedie czy leksykony i jednocześnie wyrazić przyzwolenie, by osoba prawna faktycznie została uznana za twórcę ${ }^{28}$. Takie rozwiązanie przyjęte przez francuskiego ustawodawcę sprawia, że można doszukiwać się tutaj podobieństwa do

${ }^{22} \mathrm{~K}$. Czub, Konstrukcja i treść podstawowych autorskich praw osobistych w systemie prawa francuskiego, s. 105.

${ }^{23}$ Teza wyroku w sprawie Maty v. Mauboussin, Cass. Civ., 1er, 20 mars 2001: „dzieło jest oryginalnym wytworem działalności twórczej, nawet jeśli odwołuje się do powszechnie wiadomych idei, znanych faktów czy innych elementów, uznanych za banalne. Nie można również określać stopnia oryginalności, albowiem jest to kategoria nieznana".

${ }^{24}$ T. Konach, Autorskie prawa osobiste, s. 10.

25 „L'auteur d'une oeuvre de l'esprit jouit sur cette oeuvre, du seul fait de sa création, d'un droit de propriété incorporelle exclusif et opposable à tous” („Twórcy przysługuje wyłączne prawo ochrony stworzonego dzieła, które jest skuteczne wobec osób trzecich").

${ }_{26}$ Zob. przyp. 22.

${ }^{27} \mathrm{~K}$. Czub, Konstrukcja i treść podstawowych autorskich praw osobistych w systemie, s. 117.

${ }^{28}$ F. Fuilland, Le droit moral de l'auteur en droit français, Lyon 2003, s. 12. 
amerykańskiego modelu work for hire ${ }^{29}$. Niemniej, zdaniem autorek, należy zgodzić się ze stanowiskiem doktryny, iż na podstawie brzmienia przepisów art. L.111-1 - L.111-5 Code de la propriété intelectuelle można sformułować definicję prawa osobistego autora, jako jednoczącego twórcę z jego dziełem i zapewniającego twórcy pewne przywileje względem ewentualnych użytkowników tego dzieła w sytuacji, gdy to ostatnie stanie się przedmiotem obrotu ${ }^{30}$. Znaczenie droit moral jako prawa osobistego autora, posiadające jednak pewną specyfikę na tle innych praw osobistych przysługujących osobie fizycznej na gruncie francuskiego prawa cywilnego wyrażone zostało w orzeczeniu sądu kasacyjnego z 10 marca 1993 r. ${ }^{31}$, w którym tenże sąd stwierdził, iż osobiste prawo autora dzieł literackich stanowi jedynie uprawnienie do nakazania poszanowania integralności dzieł tego twórcy lub jego nazwiska oraz uzdolnień jako autora, natomiast jest ono całkowicie obce ochronie innych chronionych normatywnie cywilnych praw osobistych ${ }^{32}$. Z uwagi na powyższe, autorskie prawa osobiste są ujmowane jako szczególne przejawy cywilnych praw podmiotowych chroniących szeroko rozumianą osobowość człowieka ${ }^{33}$.

Powyżej poczynione rozważania pozwalają sformułować tezę, iż prawa autorskie posiadają zatem (na podstawie regulacji zawartych w Code de la propriété intelectuelle) następujące cechy: są nierozerwalnie związa-

${ }^{29}$ Zgodnie z którym zamawiający/zleceniodawca lub pracodawca, który zapłacił za dzieło i podjął ekonomiczne ryzyko związane z jego powstaniem, nabywa pierwotnie prawa autorskie; obejmuje umowy o pracę (szeroko rozumiane), zamówienie dzieła; w tym przypadku pracodawca/zamawiający/zleceniodawca nie tylko nabywa w sposób pierwotny majątkowe prawa autorskie do utworu, ale ponadto jest uważany za autora dzieła. Co istotne, kwalifikacja taka następuje jedynie na potrzeby ustawy. Tak rozumiany autor work made for hire (najczęściej będzie nim osoba prawna) nie dysponuje poza tym autorskimi prawami osobistymi, bowiem w prawie amerykańskim nie przyznaje się takich praw względem wspomnianej kategorii utworów. Co osobliwe, według tej regulacji strony mogą w drodze umowy przenieść prawa autorskie do dzieła (nawet na rzeczywistego twórcę utworu), aczkolwiek bez zmiany podmiotowej autora, którym jest pracodawca/ zamawiający/zleceniodawca, niezależnie od zmiany podmiotu praw autorskich.

30 P-Y. Gautier, Propriété littéraire, s. 117.

31 Cass. Civ. 1er., 10 mars 1993.

32 F. Fuilland nazywa prawo osobiste autora "un droit de la personnalité spécifique", co ma podkreślać odrębność tych praw od innych praw osobistych chronionych przez prawo cywilne.

${ }_{33}$ C. Colombet (Propriété littéraire et artistique et droits voisins, wyd. 7, Paris 1994, s. 108) dla zobrazowania ścisłego związku pomiędzy twórcą a przysługującymi mu uprawnieniami osobistymi posługuje się porównaniem, iż autorskie prawo osobiste jest nieodłączne od osoby autora jak świeca od fosforu - „le droit moral s'attache à l'auteur comme la lueur au phosphore". 
ne z osobą twórcy, „wieczne”, nieprzenoszalne i nie podlegają przedawnieniu, o czym w dalszej części niniejszego artykułu.

Według dominującego stanowiska przedstawicieli francuskiej nauki prawa, nieprzedawnialny charakter praw osobistych jest podstawowym czynnikiem odróżniającym te prawa od uprawnień majątkowych, którym z góry pisany jest ograniczony czas trwania ${ }^{34}$. Podstaw konstrukcji prawnej przytoczonych uprawnień upatruje się w art. L. 121-1 - L. 121-9 Code de la propriété intelectuelle. W piśmiennictwie francuskim za konsekwencję niemajątkowego charakteru praw autorskich przyjmuje się również ich nieprzenoszalność niemożność całkowitego zrzeczenia się. Redakcja przepisu art. L. 121-1 Code de la propriété intelectuelle ${ }^{35}$ przesądza, iż twórca nie może zrzec się przypisanych mu praw osobistych, choć regulacja ta nie ma charakteru bezwzględnego i podlega ograniczeniom mającym na celu ochronę interesów osób trzecich. Co istotne, nieprzedawnialność autorskich praw osobistych sprowadza się w istocie do tego, że nie wygasają nawet na skutek długotrwałego ich niewykonywania. Wobec tak sformułowanego atrybutu osobistych praw autora zasygnalizować należy, iż fakt nieprzedawnialności tych praw nie jest równoznaczny z tym, że nie przedawniają się związane z prawami roszczenia. Co się zaś tyczy cechy bycia „wiecznymi”, cecha ta znajduje uzasadnienie w długowieczności samego dzieła, które może przetrwać swego twórcę i nadal odzwierciedlać jego osobowośćc ${ }^{36}$. Jest to również jedna z cech wyróżniających prawa osobiste autora od praw majątkowych przysługujących temu ostatniemu.

Odnosząc się natomiast do nieprzenoszalności autorskich praw osobistych, w orzeczeniu z 24 listopada 1997 r. sąd orzekł, że powinna ona być rozumiana szeroko, nie tylko jako niemożność przeniesienia ${ }^{37}$, lecz także jako niemożność zrzeczenia się tych praw ${ }^{38}$. Przedstawiciele doktryny

${ }^{34}$ F. Fuilland, Le droit moral de l'auteur, s. 119.

35 „L'auteur jouit du droit au respect de son nom, de sa qualité et de son oeuvre. Ce droit est attaché à sa personne. Il est perpétuel, inaliénable et imprescriptible. Il est transmissible à cause de mort aux héritiers de l'auteur. L'exercice peut être conféré à un tiers en vertu de dispositions testamentaires” („Twórca posiada prawo do ochrony jego imienia, podmiotowości i dzieła. Prawo to jest nierozerwalnie złączone z osobą twórcy. Prawo to jest dożywotnie, niezbywalne, lecz przechodzi na spadkobierców w razie śmierci twórcy. Wykonywanie tego prawa może być powierzone spadkobiercom twórcy na mocy dyspozycji testamentowej").

${ }^{36} \mathrm{M}$. Debois (Le droit d'auteur en France): „le fait, que l'oeuvre survit elle-même à son auteur, tout en restant marquée de l'empreinte de sa personnalité” („faktem jest, iż tworząc dzieło twórca naznacza je swoją osobowością").

${ }^{37}$ CA Paris, 4eme ch., 24 novembre1977.

${ }^{38}$ CA Paris, 1ere ch., 14 juin 1950. 
wskazują, iż autor nie może zrezygnować z ochrony własnej osobowości, gdyż jest to równoznaczne z popełnieniem samobójstwa duchowego/intelektualnego (suicide moral) ${ }^{39}$. Mimo tak zdecydowanych głosów w doktrynie, ta ostatnia podkreśla jednocześnie, iż nieprzenoszalność praw osobistych autora nie jest bezwzględnym atrybutem tego ostatniego, albowiem dopuszcza się w tym względzie pewne wyjątki. Najkrócej rzecz ujmując, sprowadzają się one głównie do niewykonywania określonych prerogatyw osobistych, co jest wówczas uzasadnione charakterem dzieła bądź zobowiązaniami umownymi.

Wskazując na atrybuty autorskich praw osobistych w ujęciu francuskiego ustawodawcy warty nadmienienia zdaje się być fakt obowiązywania w prawie międzynarodowym Konwencji berneńskiej o ochronie dzieł literackich i artystycznych będącej umową międzynarodową zawartą w Bernie dnia 9 września 1886 r., do której w dniu 24 lipca 1971 r. został sporządzony w Paryżu Akt paryski oraz następnie uzupełnionej w Paryżu dnia 4 maja 1896 r., zrewidowanej w Berlinie dnia 13 listopada 1908 r., uzupełnionej w Bernie dnia 20 marca 1914 r., zrewidowanej w Rzymie dnia 2 czerwca 1928 r., w Brukseli dnia 26 czerwca 1948 r., w Sztokholmie dnia 14 lipca 1967 r. oraz poprawionej dnia 2 października 1979 r. ${ }^{40}$ Zgodnie $z$ treścią art. 6 bis ust. 1 Konwencji, niezależnie od majątkowych praw autorskich, a nawet po ich ustąpieniu, autor zachowuje prawo dochodzenia autorstwa utworu, jak również prawo sprzeciwienia się wszelkiemu zniekształceniu, okaleczeniu lub innej zmianie wspomnianego utworu, która mogłaby przynieść ujmę jego godności lub dobrej sławie. Natomiast zgodnie z brzmieniem art. 7 Konwencji, czas trwania ochrony przyznanej Konwencją obejmuje życie autora i pięćdziesiąt lat po jego śmierci.

Wobec powyżej poczynionych rozważań dotyczących cech autorskich praw osobistych wskazać należy, że francuski ustawodawca przewiduje, iż autorskie prawa osobiste mogą przejść na osoby trzecie także mortis causa. Kwestia droit moral post mortem jest bowiem przedmiotem regulacji Code de la propriété intelectuelle. Wskazać należy, iż przed wejściem w życie ustawy z dnia 11 marca 1957 r., kwestia ta nie była w ogóle uregulowana przez ustawodawcę. W doktrynie coraz silniej akcentowano jednak istnienie interesu spadkobierców autora, ale jednocześnie obawę

39 A. Lucas, H.-J. Lucas, Propriété littéraire et artistique, Paris 1994, s. 195.

${ }^{40}$ Konwencja berneńska o ochronie dzieł literackich i artystycznych z dnia 9 września 1886 r., przejrzana w Berlinie dnia 13 listopada 1908 r. i w Rzymie dnia 2 czerwca 1928 r. (Dz. U. z 1935 r. Nr 84, poz. 515 z późn. zm.) w brzmieniu nadanym Aktem paryskim konwencji berneńskiej o ochronie dzieł literackich i artystycznych, sporządzonym w Paryżu dnia 24 lipca 1971 r. (Dz. U. z 1990 r. Nr 82, poz. 474, załącznik). 
budził fakt, czy ewentualny spadkobierca autora dzieła winien obejmować prawa osobiste związane z tym dziełem, skoro dzieło to wyraża osobowość li tylko jego twórcy. Wskazywano, że może wówczas dojść do niewłaściwej interpretacji woli zmarłego twórcy ${ }^{41}$. W doktrynie zaczęto zatem podkreślać, iż po śmierci twórcy przysługujące temu ostatniemu autorskie prawa osobiste stanowią gwarancję ochrony interesów duchowych (intelektualnych) nie osób, którym powierzono wykonywanie tych praw, lecz właśnie zmarłego twórcy, którego osobowość trwa poprzez jego dzieło ${ }^{42}$. W doktrynie podkreśla się, iż jest to swego rodzaju autorskie prawo osobiste "złagodzone" (droit moral allégé) albowiem spadkobierca nie posiada uprawnień, by dysponować przysługującymi autorowi prerogatywami, lecz te ostatnie winny stać się zaledwie instrumentem służącym ochronie dzieła zmarłego twórcy ${ }^{43}$.

Obecne jednak art. L. 121-2 ust. 2 Code de la propriété intelectuelle wskazuje, że po śmierci autora prawo do ujawnienia dzieła może być wykonywane przez wykonawcę ustanowionego przez twórcę. W przypadku braku tych podmiotów (albo po ich śmierci), jeżeli autor nie postanowił inaczej, prawo to winno być wykonywane kolejno przez zstępnych, małżonka (co do którego nie orzeczono separacji i niepozostającego $\mathrm{w}$ powtórnym związku małżeńskim), innych spadkobierców, którzy dziedziczą całość albo część spadku albo przez zapisobierców lub obdarowanych. Jak stanowi ust. 3 przywoływanego artykułu, prawo do ujawnienia dzieła może być wykonywane nawet po wygaśnięciu autorskich praw majątkowych. Wobec powyższego wskazać należy na rzecz podstawowa, a mianowicie na fakt, że regulacja kodeksowa obejmuje wyłącznie prawo do ujawnienia utworu przez spadkobierców zmarłego twórcy. Powyższe stało się przyczyną dla poszukiwania odpowiedzi na pytanie: jak należy traktować inne prerogatywy przysługujące zmarłemu twórcy? Także $\mathrm{w}$ tej mierze nie do przecenienia zdaje się być rola judykatury francuskiej. W orzeczeniu zapadłym w sprawie Utrillo ${ }^{44}$, sąd stwierdził, iż przepis art. L. 121-2 Code de la propriété intelectuelle reguluje wyłącznie dziedzicze-

${ }^{41}$ C. Bouloc, L'exercice du droit moral après la mort de l'auteur, Paris 2013, s. 26.

42 „Le droit moral n'est donc pas tel, après la mort, qu'auparavant, puisque les successeurs n'ont pas qualité pour prendre des décisions qui procèdent de leurs opinions ou leurs goûts: les prérogatives que l'auteur maniait à son gré, deviennent les instruments d'un devoir de fidélité” („Po śmierci twórcy autorskie prawa osobiste/niemajątkowe winny być w dalszym ciągu chronione przez działania sukcesorów prawnych zmarłego twórcy, bowiem dzieło nadal odzwierciedla przymioty osobiste twórcy i pozwala zachować jego tożsamość").

${ }^{43}$ C. Bouloc, L'exercice du droit moral, s. 27.

${ }^{44}$ Cass. civ., 1er ch.civ., 11 janvier 1989. 
nie prawa do ujawnienia dzieła po śmierci twórcy ${ }^{45}$, a prawo do poszanowania integralności dzieła nie jest przedmiotem regulacji tego przepisu, a zatem dziedziczenie tego prawa odbywa się według zasad obejmowania spadku wskazanych przez prawo cywilne ${ }^{46}$. Jednakże w doktrynie francuskiej wciąż żywa pozostaje kwestia, czy osobiste prawa autora (jako posiadające przymiot perpétuel, tj. „bycia wiecznym”) mogą z upływem czasu przejść na osoby, które nie łączy z twórcą więź osobista (rodzinna) i czy osoby niebędące $\mathrm{z}$ twórcą $\mathrm{w}$ takiej relacji mogą dojść do dziedziczenia przysługujących temu ostatniemu praw osobistych dopiero w sytuacji niemożności dziedziczenia przez wskazane w ustawie osoby. W analizie tego zagadnienia pomocne okazało się orzeczenie zapadłe w sprawie Lecomte, gdzie do dziedziczenia po zmarłym pisarzu powołana została guwernant$\mathrm{ka}^{47}$. W tym miejscu wskazać jedynie należy, że treść art. L. 121-3 ust. 1 Code de la propriété intelectuelle odsyłającego do przywołanego powyżej art. L. 121-2, traktuje o sytuacji nadużycia prawa do ujawnienia utworu, którego dopuścić się może osoba wykonująca to prawo po śmierci twórcy. Jednakże środki prawne służące zapobieganiu takim nadużyciom, jak i kwestie związane $z$ wykonywaniem praw osobistych po śmierci twórcy oraz z odstąpieniem od ich wykonywania regulowane są zarówno przez Code de la propriété intelectuelle, jak i przepisy zawarte we francuskim kodeksie cywilnym (oraz doprecyzowane przez bogate orzecznictwo).

Konsekwencją faktu, iż francuski ustawodawca przypisuje autorskim prawom osobistym konkretne atrybuty jest przyznanie autorowi/twórcy dzieła prerogatyw wyrażających wyżej wskazane atrybuty osobistych praw autorskich. Prerogatywy te obejmują: prawo do ujawnienia dzieła, prawo do poszanowania integralności dzieła, prawo do autorstwa, a także (w przypadku udostępnienia dzieła) prawo do jego modyfikacji bądź cofnięcia zgody na udostępnienie dzieła, w każdym momencie i bez konieczności uzasadniania swojej decyzji. W niniejszym artykule autorki ograniczą się do przedstawienia instytucji prawa do ujawnienia dzieła oraz prawa do poszanowania integralności dzieła.

45 „Régit exclusivement la divulgation des oeuvres posthumes” („Reguły odnoszące się wyłącznie do ujawnienia/upublicznienia działa po śmierci twórcy").

${ }_{46}$ „Les règles ordinaires de la dévolution successorale” („Przepisy dotyczące objęcia spadku").

${ }^{47}$ CA Paris, 1er ch., 14 juin 1972. 


\section{Prawo do ujawnienia (upublicznienia dzieła)}

Uprawnieniem osobistym autora, wskazanym w art. L. 121-2 Code de la propriété intelectuelle, jest prawo do upublicznienia utworu ${ }^{48}$. Przez ujawnienie utworu francuski ustawodawca rozumie wolę upublicznienia utworu obejmującą również poddanie go krytyce publiczności. W tym miejscu należy poczynić uwagę natury ogólnej, że, co prawda prawo do ujawnienia dzieła (droit de divulgation) jest uprawnieniem osobistym autora, to bezspornym jest, iż rzutuje ono także na sferę majątkowych praw twórcy. Co więcej, należy podzielić pogląd, iż droit de divulgation jest jednym z przejawów prymatu praw osobistych twórcy nad uprawnieniami majątkowymi tego ostatniego. Wskazać bowiem należy, że to autor decyduje, w jakiej formie i w jakim czasie jego dzieło ma zostać upublicznione $^{49}$. Dlatego też, jak podkreśla się $\mathrm{w}$ doktrynie, prawo do ujawnienia dzieła posiada dwa aspekty. Pierwszy, to aspekt osobisty, który pozwala autorowi zachować dzieło dla siebie. $Z$ kolei w aspekcie intelektualnym możliwe jest w pełni swobodne wstrzymanie publikacji przez autora, do momentu, gdy ten ostatni zdecyduje, iż dzieło spełnia jego osobiste oczekiwania ${ }^{50}$. Uprawnienie to jest zatem niczym innym, jak przejawem wolności osobistej autora.

Analizując kwestię wykonywania prawa do pierwszego upublicznienia dzieła należy wskazać na tezy istotnego w tej mierze wyroku Cour de Cassation wydanego w sprawie Eden v. Whistler, gdzie sąd stwierdził, że dzieło (portret) staje się własnością nabywcy dopiero po podjęciu przez autora decyzji o jego upublicznieniu ${ }^{51}$. Co istotne, w pierwszej instancji stwierdzono nawet, iż umowa, na mocy której malarz zobowiązuje się (za określonym wynagrodzeniem) wykonać portret jest szczególnego rodzaju umowa zgodnie z którą własność dzieła przechodzi ostatecznie na osobę, która je zamówiła, jednak dopiero wówczas, gdy twórca udostępni tej osobie obraz, a ona go zaakceptuje. W orzeczeniu Camoin v. Cargo sąd wskazał, że wystawienia dzieła w galerii należy bezwarunkowo uznać za

48 "L'auteur a seul le droit de divulguer son oeuvre. Sous réserve des dispositions de l'article L. 132-24 il détermine le procédé de divulgation et fixe les conditions de celle-ci" („Jedynie twórca posiada prawo do ujawnienia dzieła, co winno odbyć się z zachowaniem przepisów L. 132-24 określających procedurę i warunki takiego ujawnienia").

${ }_{49}$ C. Colombet jednoznacznie stwierdza, że prawo do upublicznienia utworu jest warunkiem powstania praw majątkowych (C. Colombet, Propriété littéraire, s. 142).

${ }^{50}$ A. Lucas, H.-J. Lucas, Propriété littéraire, s. 76.

${ }^{51}$ Cass. Civ. 14 mars 1990. 
podjęcie decyzji o pierwszym udostępnieniu tego dzieła oraz podkreślił, iż własność literacka oraz artystyczna daje uprawnionemu prawo niezwiązane z żadną korzyścią materialną natomiast artyście umożliwia upublicznienia za życia własnych dzieł, w sposób i na warunkach, które ten uzna za właściwe ( $w$ analizowanym stanie faktycznym przyznano pisarzowi prawo do zakazu upublicznienia dzieła, które twórca tego dzieła wyrzucił do kosza) $)^{52}$. Podobnie $w$ innych orzeczeniach ${ }^{53}$ sąd wskazał, że dzieło przeznaczone do nadawania drogą telewizyjną nie może ukazać się $\mathrm{w}$ formie książki bez zgody autora, podobnie jak opublikowanie zdjęć w czasopiśmie nie uprawnia do ich rozpowszechniania w programach telewizyjnych. Wydane w przywołanych sprawach orzeczenia przyczyniły się do przyjęcia poglądu, iż stosowanie prawa do upublicznienia utworu odnosić się ma do konkretnej formy takiego upublicznienia ${ }^{54}$. Wobec powyższego bezsporny zdaje się być fakt, że bogate orzecznictwo francuskie istotnie wpłynęło na treść przepisu art. L. 121-2 ust. 1 Code de la propriété intelectuelle wyrażającego zasadę, iż jedynie autor ma prawo podejmować decyzję w kwestii rozpowszechniania własnego dzieła. W tym miejscu wskazać należy na podnoszony we francuskiej doktrynie argument, że samo ujawnienie dzieła nie stanowi warunku dla powstania autorskich praw majątkowych, albowiem w myśl art. L. 111-2 Code de la propriété intelectuelle, dzieło uważa się za stworzone niezależnie od jakiegokolwiek publicznego ujawnienia, przez sam fakt realizacji, nawet niedokończonej koncepcji autora ${ }^{55}$.

Powyżej poczynione rozważania nasuwają pytanie co do samej czynności ujawnienia dzieła, w szczególności co do formy tej czynności. Otóż, zgodnie z tezą wyroku wydanego przez sąd apelacyjny w Orleanie, czynności ujawnienia dzieła powinna towarzyszyć czytelna wola jego upublicznienia ${ }^{56}$. Bogate $w$ tym zakresie orzecznictwo mnoży przykłady obejmujące zarówno sytuacje, gdy mamy do czynienia z ujawnieniem dzieła (przeniesienie własności materialnego nośnika utworu oznacza zazwyczaj intencję ujawnienia dzieła; prezentacja słowna w formie konferencji stanowi ujawnienie przedstawionego utworu), jak i te, gdy brak jest woli

52 CA Paris, 17 février 1989.

53 Cass. civ., 13 février 1981 i TGI Paris, 20 novembre 1991 (wydanym w sprawie Roland Barthes).

${ }^{54} \mathrm{~K}$. Czub, Konstrukcja i treść podstawowych autorskich praw osobistych w systemie, s. 112.

55 „L'oeuvre est réputée créée, indépendamment de toute divulgation publique, du seul fait de la réalisation, même inachevée, de la conception de l'auteur” („Dzieło uważa się za stworzone/istniejące niezależnie od tego, czy zostało ukończone, już przez sam fakt, iż odzwierciedla choćby tylko koncepcję autora").

${ }^{56}$ CA Orléans, 18 février 1959. 
upublicznienia dzieła (z prawa do ujawnienia dzieła nie można skorzystać wobec galerii posiadającej modele gipsowej rzeźby, gdy ustalono, że dzieła te były już przedmiotem licznych reprodukcji). Wobec powyższego istotna zdaje się być teza wyroku z dnia 20 listopada 1991 r., w którym sąd stwierdził, że nagranie wykładu przez słuchaczy czy zwięzłe przedstawienie w czasopiśmie uczelni nie stanowiły ujawnienia wykładu, a także wskazał, iż upublicznienie utworu w jednej z możliwych postaci nie wyczerpuje prawa do decydowania o innych sposobach ujawnienia dzieła ${ }^{57}$, choć autor powinien zakomunikować wszelkie zamierzone przez siebie ograniczenia odnośnie do formy ujawnienia utworu. Analizując zagadnienie prawa do ujawnienia dzieła, wskazać należy na wpływ własności nośnika dzieła na to prawo. W tej mierze kluczowa zdaje się być teza orzeczenia wydanego w sprawie Rouault ${ }^{58}$, zgodnie z którą autorowi przysługuje prawo domagania się wydania egzemplarza nieujawnionego utworu, nawet jeśli znajduje się on we władztwie posiadacza w dobrej wierze. Powyższe nie oznacza jednak możliwości bezwarunkowego wydania czy zniszczenia nośnika ani też możliwości zwrotnego żądania przeniesienia własności. Zgodnie bowiem z treścią art. L. 111-3 ust. 2 Code de la propriété intelectuelle, w przypadku nadużycia prawa własności egzemplarza dzieła w celu uniemożliwienia wykonania prawa do ujawnienia, twórca, bądź po śmierci autora, osoby uprawnione do wykonywania praw odnoszących się do autorskich dóbr osobistych zmarłego, mogą się domagać czasowego wydania dzieła w celu realizacji prawa do ujawnienia ${ }^{59}$.

\section{Prawo do zachowania integralności utworu}

Prawo do zachowania integralności utworu wyrażone jest w Code de la propriété intelectuelle oraz doprecyzowane w bogatym orzecznictwie sądów francuskich. Ogólną podstawę normatywną dla tego uprawnienia osobistego twórcy stanowi art. L. 121-1 ust. 1, zgodnie z którym autorowi przysługuje prawo do poszanowania jego utworu. Doprecyzowaniem tej ogólnej zasady jest treść przepisu art. L. 132-2 ust. 2 i art. L. 132-22 Code de la propriété intelectuelle. Zgodnie z treścią tego pierwszego, wydawca

\footnotetext{
57 TGI Paris, 20 novembre 1991.

58 CA Orléans, 17 mars 1965.

${ }^{59}$ F. Fuilland, Le droit moral de l'auteur, s. 26.
} 
nie może bez pisemnej zgody twórcy wprowadzać zmian do utworu ${ }^{60}$. Z kolei zgodnie z treścią art. L. 132-22, przedsiębiorca teatralny powinien zapewnić wystawienie spektaklu lub publiczne wykonanie w warunkach, które gwarantują poszanowanie praw własności intelektualnej i praw osobistych autora ${ }^{61}$. Zasada nienaruszalności utworu dąży do wzmocnienia pozycji autora $\mathrm{w}$ stosunku do nabywców egzemplarzy dzieł i ochrony dzieła przed bezprawnym zniekształceniem ${ }^{62}$. Choć właściciel egzemplarza dzieła, kontrahent twórcy czy osoba trzecia nie może bez zgody autora dokonywać w utworze jakichkolwiek zmian (a samo prawo do integralności utworu obejmuje także przedmowę, wprowadzenie, tytuł), to prawo takie nie ma jednak charakteru bezwzględnego, o czym w dalszej części niniejszego artykułu.

U podstaw prawa do integralności utworu wyrażonego przez francuskiego ustawodawcę tkwi indywidualizm francuskiego systemu prawa autorskiego, przejawiający się w przyznaniu ochrony integralności utworu nie tyle $\mathrm{z}$ racji istnienia interesu społecznego, co samego faktu stworzenia dzieła, ujmowanego jako wyraz osobowości jego twórcy oraz przyznania wyłącznie temu ostatniemu prawa decydowania o kształcie utworu. Najpełniejszym tego wyrazem jest teza orzeczenia wydanego w sprawie En attendant Godot, gdzie orzeczono, że nikt nie może oceniać wartości woli autora, tylko on decyduje o charakterze integralności dzieła ${ }^{63}$. Jednak w sprawie Salvador Dali sąd uznał, że na prawo do integralności utworu można się powoływać tylko wtedy, gdy konsekwencją zmian jest nadanie

60 „L'éditeur est tenu d'effectuer ou de faire effectuer la fabrication ou la réalisation sous une forme numérique selon les conditions, dans la forme et suivant les modes d'expression prévus au contrat. Il ne peut, sans autorisation écrite de l'auteur, apporter à l'oeuvre aucune modification” („Wydawca obowiązany jest zachować formę, cechy, środki wyrazu wskazane przez autora i nie może bez zgody autora wprowadzać żadnych zmian do utworu").

61 „L'entrepreneur de spectacles doit assurer la représentation ou l'exécution publique dans des conditions techniques propres à garantir le respect des droits intellectuels et moraux de l'auteur" („Wystawiający spektakl obowiązany jest zachować takie warunki, by podczas wystawienia spektaklu zapewnić poszanowanie praw autora, które ten spektakl odzwierciedla").

${ }^{62} \mathrm{~K}$. Czub, Konstrukcja i treść podstawowych autorskich praw osobistych w systemie, s. 119.

63 „Le respect est dû à l'oeuvre telle que l'auteur a voulu qu'elle soit. Il n'appartient ni aux tiers, ni au juge de porter un jugement de valeur sur la volonté de l'auteur le titulaire du droit moral étant seul maître de son oeuvre” („,Określenie charakteru integralności dzieła należy wyłącznie do twórcy. Do dokonania oceny nie są uprawnione osoby trzecie ani sędzia orzekający w konkretnej sprawie, bowiem jest to sfera osobistych praw niemajątkowych twórcy"). 
dziełu nieprawidłowego charakteru ${ }^{64}$. Jak słusznie podkreślają przedstawiciele doktryny, przy ocenie ewentualnego naruszenia należy co do zasady rozważyć, czy zmiana jest zgodna $\mathrm{z}$ charakterem utworu ${ }^{65}$. Istotny zdaje się być ponadto fakt, iż prawo do poszanowania utworu nie odnosi się do naruszenia dobrej sławy i czci autora. Tego typu dobra pozostają pod ochroną prawa powszechnego.

Jak już wspomniano, prawo do poszanowania integralności utworu nie ma charakteru absolutnego, a zatem poddane jest pewnym ograniczeniom, co także stało się przedmiotem orzeczeń sądów francuskich. Warto w tym miejscu przytoczyć tezę wyroku wydanego w sprawie Dubuffet, gdzie w kwestii zmiany kompozycji lodówki użytej za podstawę utworu artysty przez jej nabywcę, wskazano na wyłączną kompetencję twórcy do ustalenia kształtu i formy dzieła, odwołując się do subiektywnego odczucia twórcy, które faktycznie wyznacza zakres analizowanego uprawnienia $^{66}$. Na marginesie wskazać należy, że w tej samej sprawie sąd wskazał na inną istotną rzecz, a mianowicie, iż autorskie prawa osobiste posiadają dorozumiane pierwszeństwo przed prawem własności nośnika ucieleśniającym dzieło. Jednakże jednym z pierwszych orzeczeń w przedmiocie charakteru prawa do integralności utworu był wyrok zapadły w sprawie Fresques de Juvisy, wydany 27 kwietnia 1934 r., w którym wskazano na cechę absolutyzmu prawa własności wysłowioną w treści art. 544 francuskiego kodeksu cywilnego ${ }^{67}$, przyznając, iż nabywcy przysługuje prawo do dysponowania dziełem, w tym do jego unicestwienia. Należy jednak każdorazowo rozważyć, czy dany utwór przeznaczony był do użytku prywatnego czy też stanowił dobro wystawiane dla szerszego grona odbiorców. Tak w wyroku z 25 lipca 1975 r., w sprawie Scrive, sąd wskazał, że nie należy usuwać rzeźby z centrum handlowego, gdyż przeznaczona była do odbioru w miejscu publicznym, czyli brak było okoliczności uzasadniających subiektywną wolę właściciela. Jednakże w wyroku wydanym w sprawie Parc de Grenoble sąd uznał, iż dzieło może być usunięte z miejsca publicznego przez wzgląd na bezpieczeństwo publiczne ${ }^{68}$.

${ }^{64}$ CA Paris, 11 mai 1965.

65 Sprawa Brel, CA Paris, 21 juin 1988.

${ }^{66}$ Cas. civ. 1 ere ch., 6 juillet 1965.

67 „La propriété est le droit de jouir et disposer des choses de la manière la plus absolue, pourvu qu'on n'en fasse pas un usage prohibé par les lois ou par les règlements" („Własność dzieła jest prawem bezwzględnie przysługującym autorowi, która znajduje ochronę w normach wysłowionych w przepisach oraz regułach konstruowanych na podstawie tych przepisów").

${ }^{68}$ T. Adm. Grenoble, 18 février 1976. 
Istotne zdaje się być również zagadnienie dokonania modyfikacji utworu, które to zmiany będą wpływały na późniejsze wykorzystanie utworu. Chodzi tutaj głównie o zmiany dokonane przez wydawcę, a mające za przedmiot korektę błędów ortograficznych, interpunkcyjnych czy składniowych, w czym przejawia się pewna swoboda wydawcy (czy innego podmiotu eksploatującego utwór). Spod zakresu tych modyfikacji wyłączone są jednak błędy stylistyczne. Także w przypadku dzieł, które stanowią dla pewnej grupy odbiorców swoiste narzędzie pracy (jak podręczniki szkolne, encyklopedie), zważywszy na ich specyficzny charakter wynikający $z$ regulowanej przez nie materii, mogą być uzupełniane, zwłaszcza $\mathrm{w}$ przypadku, gdy zawarte $\mathrm{w}$ nich informacje utraciły aktualność. Jednak twórca (częściej twórcy) nie jest wówczas całkowicie pozbawiony wpływu na kształt dzieła, albowiem może skorzystać z licznych uprawnień, jak choćby żądanie wydzielenia zmodyfikowanych fragmentów czy opatrzenia całości dzieła komentarzem (objaśnieniem), które to stanowisko potwierdza judykatura francuska ${ }^{69}$. Jednakże, gdy przedmiotem ewentualnych zmian są dzieła stricte naukowe czy literackie, osoba eksploatując utwór nie posiada już swobody w zakresie ingerencji w treść takiego dzieła. Wydawca nie może od twórcy żądać aktualizacji utworu $\mathrm{z}$ uwagi na jego charakter ${ }^{70}$. Innego rodzaju ograniczenia dotyczyć moga współautorstwa dzieła. W niniejszym artykule autorki ograniczą się jednak do wskazania, że Code de la propriété intelectuelle reguluje kilka rodzajów współautorstwa, co nie zostało poddane głębszej analizie w niniejszym artykule, a jest przedmiotem przepisów kodeksowych i orzeczeń sądowych.

\section{Zakończenie}

Konstrukcja normatywna autorskich praw osobistych przyjęta przez francuskiego ustawodawcę stanowi odzwierciedlenie wypracowanego przez judykaturę personalistycznego podejścia do treści tych praw. Zgodnie z treścią wskazywanej koncepcji, stworzony przez autora utwór (dzieło) jest pojęciem zasadniczym, to jednak posiada on wartość z racji faktu, że jest uzewnętrznieniem osobowości autora. Francuski ustawodawca $w$ przepisach dotyczących osobistych praw autorskich, $\mathrm{z}$ jednej

${ }^{69}$ CA Paris, 12 janvier 1848 oraz CA Bordeaux, 24 août 1863.

${ }^{70}$ F. Fuilland, Le droit moral de l'auteur, s. 28. 
strony akcentuje występowanie przymiotów osobistych autora (co jest osobliwością francuskiego ustawodawstwa w tym zakresie), z drugiej zaś wskazuje, iż warunkiem skorzystania z ochrony przyznanej tym prawom jest konieczność skonkretyzowania przymiotów twórcy, czyli po prostu powstanie utworu (dzieła). W tym kontekście wskazać należy na brak wątpliwości co do prymatu autorskich praw osobistych nad uprawnieniami majątkowymi twórcy, jednakże zastrzec jednocześnie należy zależność istniejącą pomiędzy obydwoma kategoriami praw przysługujących twórcy. Zależność ta szczególnie uwidacznia się na gruncie realizacji prawa do ujawnienia (upublicznienia) dzieła, które to ujawnienie najczęściej wiąże się z uzyskaniem korzyści materialnych. Wobec powyższego warto nadmienić, że środki prawne służące ochronie majątkowych i niemajątkowych praw przysługujących autorowi uregulowane są nie tylko w Code de la propriété intelectuelle lecz także w przepisach francuskiego kodeksu cywilnego. Niech najpełniejszym wyrazem francuskiego indywidualizmu w dziedzinie autorskich praw osobistych będą słowa autora ustawy dotyczącej praw autorskich, ogłoszonej we Francji już w 1791 r.: „najświętsze, najbardziej uzasadnione, najbardziej niepodważalne i najbardziej osobiste ze wszystkich dóbr jest dzieło będące owocem myśli pisarza $(\ldots)^{\prime \prime 71}$.

Słowa kluczowe: prawo autorskie, prawa niemajątkowe, własność intelektualna, dzieło, utwór

\section{Bibliografia}

Czub K., Konstrukcja i treść podstawowych autorskich praw osobistych w systemie prawa francuskiego, „Studia Iuridica Toruniensia” 2009, t. 5.

Debois H., Le droit d'auteur en France, Paris 1978.

Fuilland F., Le droit moral de l'auteur en droit français, Lyon 2003.

Gautier P-Y., Propriété littéraire et artistique, Paris 1990.

Górnicki L., Rozwój idei praw autorskich od starożytności do II wojny światowej, Wrocław 2013.

Konach T., Autorskie prawa osobiste w ustawodawstwach Francji i Republiki Federalnej Niemiec - analiza prawnoporównawcza, „Ruch Prawniczy, Ekonomiczny i Socjologiczny" 2014, z. 3.

Lucas A., Lucas H.-J., Propriété littéraire et artistique, Paris 1994.

${ }^{71}$ „La plus sacrée, la plus légitime, la plus inattaquable, et, si je puis parler ainsi, la plus personnelle de toutes les propriétés, est l'ouvrage fruit de la pensée d'un écrivain $(\ldots)^{\prime \prime}$. 
Morillot A., De la personnalité du droit de copie qui appartient à un auteur vivant, Paris 1872.

Niżankowska A., Prawo do integralności utworu, Warszawa 2007.

\section{DROIT MORAL, THAT HAS NOTHING TO DO WITH MORALITY, IE COPYRIGHT LAWS PERSONAL FRENCH LAW}

\section{S u m m a r y}

France is considered the cradle of the creation of copyright in the continental legal system. At the time of the French Revolution, you can find the origins of the concept of ideological actions for safeguarding the interests of non makers. A significant role in shaping the legal regulations for safeguarding copyright law played. The necessity of resolving disputes relating to the protection of copyright non-property rights in the absence of normative basis for the settlement of these disputes has become a cause for the creation of legal regulations in this regard. Currently normative source govern the protection of copyright non-property rights in France is mainly the Intellectual Property Code and to some extent also the civil code. Based on the analysis mentioned in the previous sentence can be set to formulate a general conclusion that the basis for the author's personal rights to a French law recognizing the integrity of the person the creator and his work. French legislature in the content of the Intellectual Property Code is typical for copyright and legal tools to protect those rights. Special protection French law subjects the right to preserve the integrity of the work and the right to disclose the work on which leans author of this study.

Key words: copyright non-property rights, Intellectual Property Code, preserve the integrity, creator, the author's personal rights

\section{DROIT MORAL, КОТОРОЕ НЕ ИМЕЕТ НИЧЕГО С МОРАЯЬНОСТЬЮ, ТО ЕСТЬ ОБ АВТОРСКИХ ЛИЧНЫХ ПРАВАХ В СИСТЕМЕ ФРАНЦУЗСКОГО ПРАВА}

$$
\text { P e } 3 \text { г м е }
$$

Франция считается колыбелью восстания авторских прав в континентальной юридической системе. Уже во времена Большой Французской Реводюции можно отыскать начала идеологических концепций, которые имеют за предмет зашиты неимущественных интересов творца. Значимую роль в сфере формирования юридических регулирований, имеющих за предмет защиты авторских прав, сыграло судовая практика. Необходимость решения споров, касающихся защиты авторских неимущественных прав при недостатке нормативных оснований для решения этих споров, стала причиной для создания юридических регулирований 
в этой сфере. На данный момент нормативный источник, регулирующий способ защиты авторских неимущественных прав во Франции, представляет в основном кодекс интеллектуальной собственности, а также в определенной сфере гражданский кодекс. На основании анадиза указанных в предыдущем предложении законов можно сформулировать общее предложение, что основу для личных прав автора составляет во французском праве признание недедимости лица творца и его произведения. Французский законодатель в содержании положений кодекса интеллектуальной собственности указывает на признаки авторских прав и на юридические инструменты, которые защищают эти права. Особенной защите французское право подвергает право на сохранение целостности произведения и право на выявление дела, к чему приклонялся автор данной разработки.

Ключевые слова: авторское право, неимущественные права, интеллектуальная собственность, произведение, творение 